\title{
PENGARUH KETERLIBATAN GURU-SISWA DALAM MENULIS KARANGAN EKSPOSISI MENGGUNAKAN MODEL EXPERIENTIAL LEARNING DI SMA NEGERI 2 INDRAMAYU
}

\author{
Embang Logita ${ }^{1}$, Nana Triana Winata ${ }^{2}$ \\ ${ }^{1}$ Universitas Wiralodra, embanglogita@ rocketmail.com \\ ${ }^{2}$ Universitas wiralodra, nanawinata26@gmail.com
}

\begin{abstract}
In learning expositional text, there is material to identify, compile, analyze, and produce. Producing as a final project of learning exposition text because in producing students are able to think critically and student are considered to have mastered the material about identifiying, compiling and analyzing. Producing in exposition text materian in the form of writing.

The use of models, methods and techniques in learnin exposition text is very important to help students more easily understand the subject conveyed by the teacher. The use of experiential learning in the learning process is an effort to develop and build student'klowlegde through their experiences.

Teacher-student involvement through an experiential learning models based on student intelligence to improve skills in producing exposition text is a models that involves the active role of student by writing down their own ideas based on the experiences of student who vary according to their reseptive intellegences so that each student in producing exposition text will be varied so that this learning models is expected to help student develop or improve wrting skill especially in producing text.
\end{abstract}

Keyword: exposition text, experiential learning, teacher-student involvement

\section{ABSTRAK}

Dalam pembelajaran teks eksposisi terdapat materi mengidentifikasi, menyusun, menganalisis dan memproduksi. Memproduksi sebagai tugas akhir dari pembelajaran teks eksposisi karena dalam memproduksi siswa mampu berfikir kritis dan siswa dianggap sudah menguasai materi tentang menidentifikasi, menyusun, dan menganalisis. Memproduksi dalam materi teks eksposisi berupa menulis.

Penggunaan model, metode atau teknik dalam pembelajaran teks eksposisi sangatlah penting untuk membantu siswa lebih mudah memahami pokok bahasan yang disampaikan oleh guru. Penggunaan model pengalaman (experiential learning) di dalam proses pembelajaran merupakan salah satu upaya untuk mengembangkan dan membangun pengetahuan siswa melalui pengalamannya.

Keterlibatan guru-siswa melalui model experiential learning yang berbasis kecerdasan siswa untuk meningkatkan keterampilan memperoduksi teks eksposisi merupakan model yang melibatkan peran peserta didik secara aktif dengan menuliskan ide-ide pikirannya sendiri berdasarkan pengalaman siswa yang bermacam-macam sesuai dengan kecerdasan masingmasing. Setiap siswa mempunyai kecerdasan masing-masing sehingga setiap siswa dalam memproduksi teks eksposisi akan menjadi bervariasi sehingga dengan model pembelajaran ini 
diharapkan dapat membantu peserta didik dalam mengembangkan atau meningkatkan keterampilan menulis khususnya dalam memproduksi teks.

Kata Kunci: teks eksposisi, experiential learning, keterlibatan guru-siswa

How to Cite: Logita, E., \& Triana Winata, N. (2020). PENGARUH KETERLIBATAN GURU-SISWA DALAM MENULIS KARANGAN EKSPOSISI MENGGUNAKAN MODEL EXPERIENTIAL LEARNING DI SMA NEGERI 2 INDRAMAYU. Bahtera Indonesia; Jurnal Penelitian Bahasa Dan Sastra Indonesia , 5(2), 204-221. https://doi.org/10.31943/bi.v5i2.96

DOI: https://doi.org/10.31943/bi.v5i2.96

\section{PENDAHULUAN}

\section{Pengertian Pembelajaran}

Dalam keseluruhan proses pendidikan di sekolah, pembelajaran merupakan aktivitas yang paling utama. Ini berarti bahwa keberhasilan pencapaian tujuan pendidikan banyak bergantung pada bagaimana proses pembelajaran dapat berlangsung secara efektif. Pemahaman seorang guru terhadap pengertian pembelajaran sangat mempengaruhi cara guru itu mengajar.

Menurut Douglas Brown (2008: 8) pembelajaran adalah penguasaan atau pemerolehan pengetahuan tentang suatu subjek atau sebuah keterampilan dengan belajar, pengalaman, dan intruksi. Sedangkan menurut Fathurrohman (2017:16) pembelajaran adalah proses interaksi peserta didik dengan pendidik dan sumber belajar pada suatu lingkungan belajar. Jadi pembelajaran adalah proses perubahan tingkah laku yang disebabkan oleh pengalaman.

\section{Pengertian Bahasa}

Menurut Soenjono (2016: 16) Bahasa adalah suatu sistem simbol lisan yang arbitrer dipakai oleh anggota suatu masyarakat bahasa untuk berkomunikasi dan berinteraksi antar sesamanya berlandaskan pada budaya yang mereka miliki bersama. Sedangkan menurut
Kridalaksana (dalam Kentjono1997: 1) "bahasa adalah sistem lambang bunyi yang arbiter yang digunakan oleh anggota kelompok sosial untuk bekerjasama, berkomunikasi dan mengidentifikasi diri". Dalam hal ini bahasa sebagai alat komunikasi yang digunakan oleh masyarat dalam kehidupan sehari-hari untuk menyampaikan pesan dan maksud.

\section{Pengertian Menulis}

Menurut Eli Herlina (2016: 1) menyatakan bahwa menulis didefinisikan sebagai suatu kegiatan penyampaian pesan (komunikasi) dengan menggunakan bahasa tulis sebagai alat atau medianya. Sedangkan Menurut Henry Guntur Tarigan (2008: 22) menulis ialah menurunkan atau melukiskan lambang-lambang grafik yang menggambarkan suatu bahasa yang dipahami oleh seseorang, sehingga orangorang lain dapat membaca lambanglambang grafik tersebut kalau mereka memahami bahasa dan grafik tersebut.

Jadi dari penjelasan para ahli di atas dapat disimpulkan bahwa menulis adalah penyampaian pesan dalam bentuk tulisan yang dapat dipahami oleh orang lain. Dalam menulis seseorang dituntut untuk mengekspresikan dan menuangkan ide atau gagasannya dalam suatu tulisan. Agar tulisan tersebut dapat dinikmati oleh orang lain maka terdapat fungsi dan tujuannya. 
Menurut Tarigan (2008: 22) "Pada prinsipnya fungsi utama dari tulisan adalah sebagai alat komunikasi yang tidak langsung. Menulis sangat penting bagi pendidikan karena memudahkan para pelajar berfikir, juga dapat menolong berpikir secara kritis, juga dapat memudahkan kita merasakan dan menikmati hubungan-hubungan, memperdalam daya tangkap atau persepsi kita, memecahkan masalah-masalah yang kita hadapi, menyusun urutan bagi pengalaman. Tulisan dapat membantu kita menjelaskan pikiran-pikran kita”.

Dalam uraian di atas penulis dapat menyimpulkan fungsi menulis sebagai berikut:

1. Menulis sebagai alat komunikasi tidak langsung

2. Menulis dapat memudahkan pelajar berpikir

3. Membantu kita dalam berfikir kritis

4. Menuyusun urutan dalam pengalaman.

Selain terdapat fungsi, menulis pun ada tujuannya. Menurut Hugo Hartig (dalam Tarigan 2008: 25) sebagai berikut:

1. Tujuan Penugasan

Tujuan penugasan ini sebenarnya tidak mempunyai tujuan sama sekali.Penulis menulis sesuatu karena ditugasi, bukan atas kemauan sendiri.

2. Tujuan Altuistik

Penulis bertujuan untuk menyenangkan para pembaca, menghindarkan kedudukan para pembaca, ingin menolong para pembaca memahami, menghargai perasaan dan penalarannya, ingin membuat hidup para pembaca lebih menyenangkan dengan karyanya itu.

3. Tujuan Persuasif tulisan bertujuan menyakinkan para pembaca akan membenarkan gagasan yang diuraikan.

4. Tujuan Penerangan

Tulisan yang berhubungan memberi informasi atau keterangan/penerangan kepada para pembaca.

5. Tujuan Pernyataan Diri.
Tujuan yang bertujuan memperkenalkan atau menyatakan diri sang pengarang kepada para pembaca.

6. Tujuan Kreatif

Tujuan ini erat berhubungan dengan tujuan pernyataan diri. tetapi "keinginan kreatif' di sini melebihi pernyataan diri, dan melibatkan dirinya dengan keinginan mencapai norma artistik, atau seni yang ideal, seni idaman. Tulisan yang bertujuan mencapai nilai-nilai kesenian.

7. Tujuan Pemecahan Masalah

Dalam tulisan seperti penulis ingin memecahkan masalah yang di pahami. Sang penulis ingin menjelaskan, menjernihkan,serta menelaah serta meneliti secara cermatpikiran-pikiran dan gagasan sendiri agar dapat dimengerti dan diterima oleh pembaca.

Dalam menulis selain ada tujuan terdapat ragamnya, menurut Weayer (dalam Tarigan 2008: 28) membuat klasifikasi ragam tulisan berdasarkan bentuk,sebagai berikut:

1. Narasi adalah tulisan yang bertujuan menjelaskan atau menceritakan sesuatu.

2. Eksposisi adalah tulisan yang bertujuan untuk menguraikan, menjelaskan maksud dan tujuan.

3. Deskriptif adalah tulisan yang memaparkan atau menggambarkan dengan menggunakan kata-kata jelas dan terperinci.

4. Argumentasi adalah tulisan yang bertujuan untuk memperkuat atau mengolah suatu pendapat, pendirian, atau gagasan.

5. Persuasif adalah yang bertujuan untuk mengajak kepada seseorang dengan cara memberikan alasan dan prospek baik yang menyakinkan.

\section{Eksposisi}

Eksposisi merupakan teks yang menyajikan pendapat atau gagasan yang dilihat dari sudut pandang penulisnya dan berfungsi untuk meyakinkan pihak lain bahwa argumen- 
argumen yang disampaikannya itu benar dan berdasarkan fakta-fakta. Isi eksposisi adalah pendapat penulis untukmeyakinkan orang lain berdasarkan fakta.

Struktur teks eksposisi terdiri dari:

a) Tesis atau peryataan pendapat,

b) Argumentasi,

c) Penegasan Ulang.

Ciri kebahasaan teks eksposisi adalah

a) Menggunakan istilah.

b) Menggunakan kata sifat.

c) Perubahan jenis kata karena afiksasi (pengimbuhan).

d) Menggunakan kalimat verbal.

\section{Pengertian Model Ekperiential Learning}

Dalam proses belajar mengajar kehadiran model mempunyai arti yang cukup penting. Karena dalam kegiatan tersebut model dapat membantu berjalannya pembelajaran.model dapat diartikan sebagai rancangan pengkondisian siswa. Model yang ingin dikaji dalam skripsi ini adalah experiential laerning. Model experiential learning adalah pembelajaran yang melibatkan pengalamann siswa. Menurut Fathurrohman (2017: 128) bahwa pembelajaran dengan model experiential learning mulai diperkenalkan pada 1984 oleh David Kolb "model pembelajaran berbasis pengalaman mendefisinikan belajar sebagai proses mengkontruksi pengetahuan melalui transformasi pengalaman".Adapun tahap-tahapnya sebagai berikut:

1. Guru merumuskan secara seksama suatu rencana pengalaman belajar yang bersifat terbuka mengenai hasil yang potensial atau memiliki seperangkat hasil-hasil tertentu.

2. Guru harus bisa memberikan rangsangan dan motivasi pengenalan terhadap pengalaman.

3. Peserta didik dapat bekerja secara individu atau bekerja secara kelompokkelompok kecil/keseluruhan kelompok di dalam belajar berdasarkan pengalaman.
4. Para peserta didik ditempatkan pada situasi-situasi nyata.

5. Peserta didik aktif berpartisipasi di dalam pengalaman yang tersedia, membuat keputusan sendiri, dan menerima kosenkuensi berdasarkan keputusan tersebut.

Keseluruhan kelas menyajikan pengalaman yang telah dituangkan ke dalam tulisan sehubungan dengan mata pelajaran tersebut untuk memperluas pengalaman belajar dan pemahaman peserta didik dalam melaksanakan pertemuan yang nantinya akan membahas bermacam-macam pengalaman tersebut.

\section{METODE PENELITIAN}

Berdasarkan latar belakang penelitian, metode yang dianggap tepat untuk penelitian ini adalah metode penelitian studi eksperimen. Dalam studi eksperimen, pengukuran kemampuan memproduksi teks eksposisi peserta didik dilakukan sebelum dan sesudah sampel penelitian diberi perlakuan dengan model experiential learning yang berbasis kecerdasan siswa dalam bentuk menulis teks eksposisi berdasarkan pengalaman siswa sesuai kecerdasan masing-masing siswa. Sampel dalam penelitian ini adalah kelas $\mathrm{X}$ IPA 3 SMAN 2 Indramayu sebagai sampel penelitian dengan jumlah 24 siswa $(20 \%$ dari seluruh populasi).

Desain penelitian pada penelitian ini menggunakan model "One group prestest posttest design", dimana eksperimen ini dilaksanakan pada satu kelompok pembanding. Jelas dapat digambarkan dalam bagan sebagai berikut:

\begin{tabular}{|c|c|c|}
\hline Pretest & Perlakuan & Posttes \\
\hline O1 & $\mathrm{X}$ & $\mathrm{O} 2$ \\
\hline
\end{tabular}

Keterangan: 
O1

sebelum diberi perlakuan

$\mathrm{O} 2 \quad$ : Nilai Postest

sesudah diberi perlakuan

$$
\mathrm{X} \quad \text { : Perlakuan }
$$

Desain penelitian di atas, menggunakan satu subjek penelitian, Pertama subjek penelitian diberi pretest atau tes awal terlebih dahulu tanpa diberi perlakuan mengenai materi memproduksi teks eksposisi. Kedua, subjek penelitian diberi posttest atau tes akhir untuk pembelajaran memproduksi teks eksposisi dengan diberi perlakukan yaitu menggunakan model experiential learning berdasarkan kecerdasan siswa.

\subsection{Instrumen Penelitian}

Instrumen Penelitian yang digunakan dalam penelitian ini yaitu tes. Instrumen berupa tes kemampuan menulis teks ekposisi dengan berpedoman pada pedoman penilaian.

\subsection{Teknik Penelitian}

\subsubsection{Teknik Pengumpulan Data}

Teknik pengumpulan data dalam penelitian ini adalah dengan tes hasil belajar. Teknik tes yang digunakan ada dua, yaitu:

1) Pre-test atau tes awal. Hasil tes yang dijadikan data penelitian berupa kemampuan menulis siswa.

2) Post-test atau tes akhir. Hasil tes yang dijadikan data penelitian berupa kemampuan menulis siswa dalam memproduksi teks eksposisi.

Melalui pembelajaran pre-test dan post-test peneliti dapat mengetahui adanya perbedaan hasil pembelajaran kemampuan menulis atau memproduksi teks eksposisi sebelum dan sesudah menggunakan model experiential learning yang berbasis kecerdasan siswa.

\section{Teknik Pengolahan Data}

Berikut dipaparkan langkahlangkah proses pengolahan data dalam penelitian ini:

1. Memeriksa dan menentukan nilai pretes dan postes atas objek penelitian dengan dua orang penilai

2. Karena tes berupa tes menulis maka penulis melakukan uji reliabilitas antar penimbang untuk skor prestes dan postes.

3. Uji normalitas dengan menggunakan Chi Kuadrat

4. Uji signifikansi perbedaan rata-rata pretes dan postes dengan langkah uji-t

5. Menghitung perbedaan rerata uji-t.

6. Mencari derajat kebebasan.

7. Memilih tabel dengan taraf signifikasi 5\% atau taraf kepercayaan $95 \%$

8. Menguji signifikansi koefisien ttabel.

\section{HASIL PEMBAHASAN}

A. Hasil Kemampuan Memproduksi Teks Eksposisi Siswa Kelas X IPA 3 SMA Negeri 2 Indramayu Tahun Pelajaran 2020/2021 Sebelum Pembelajaran (Pretes) dengan Model Experiential Learning

\begin{tabular}{|c|l|c|c|c|c|c|c|c|c|}
\hline \multirow{2}{*}{ No } & \multirow{2}{*}{ Nama } & \multicolumn{5}{|c|}{ Aspek yang Dinilai } & \multirow{2}{*}{ Skor } & \multirow{2}{*}{ Nilai } & \multirow{2}{*}{ Klasifikasi } \\
\cline { 3 - 9 } & & 1 & 2 & 3 & 4 & 5 & & & \\
\hline 1 & Aa Anggara Al A. & 5 & 7 & 10 & 15 & 10 & 47 & 47 & Kurang \\
\hline 2 & Abu Hasan A. & 2 & 5 & 10 & 15 & 15 & 47 & 47 & Kurang \\
\hline 3 & Ais Indah Ayu & 10 & 10 & 10 & 15 & 10 & 55 & 55 & Kurang \\
\hline 4 & Al Harist B. H. & 7 & 10 & 15 & 15 & 5 & 52 & 52 & Kurang \\
\hline 5 & Anisa Murdiyana & 15 & 15 & 15 & 15 & 5 & 65 & 65 & Cukup \\
\hline 6 & Cica Kartika A. R & 10 & 10 & 15 & 15 & 5 & 55 & 55 & Kurang \\
\hline
\end{tabular}




\begin{tabular}{|c|l|c|c|c|c|c|c|c|c|}
7 & Elok Faiqotul H. & 2 & 5 & 5 & 10 & 10 & 32 & 32 & Kurang \\
\hline 8 & Hasan Nurudin R. & 10 & 10 & 10 & 15 & 10 & 55 & 55 & Kurang \\
\hline 9 & Ica Kristi & 7 & 10 & 7 & 15 & 5 & 44 & 44 & Kurang \\
\hline 10 & Indah Apriyana & 7 & 10 & 15 & 15 & 10 & 57 & 57 & Cukup \\
\hline 11 & Kartika & 7 & 10 & 10 & 15 & 15 & 57 & 57 & Cukup \\
\hline 12 & Kayla Amelia L. & 7 & 10 & 10 & 10 & 20 & 57 & 57 & Cukup \\
\hline 13 & Meilisa Windi F. & 7 & 10 & 10 & 10 & 10 & 47 & 47 & Kurang \\
\hline 14 & Mely Nurhasanah & 15 & 15 & 15 & 15 & 10 & 70 & 70 & Cukup \\
\hline 15 & Muhamad Soltan & 7 & 10 & 15 & 15 & 10 & 57 & 57 & Cukup \\
\hline 16 & Ninda Nurhayati & 15 & 15 & 10 & 15 & 5 & 60 & 60 & Cukup \\
\hline 17 & Nisa Setyani & 5 & 10 & 15 & 15 & 5 & 50 & 50 & Kurang \\
\hline 18 & Nur Habibah & 7 & 10 & 15 & 10 & 10 & 52 & 52 & Kurang \\
\hline 19 & Nurhaenih & 12 & 12 & 5 & 15 & 5 & 49 & 49 & Kurang \\
\hline 20 & Sandi Subandi & 7 & 7 & 12 & 15 & 5 & 46 & 46 & Kurang \\
\hline 21 & Sofi Khamelia & 7 & 10 & 15 & 15 & 10 & 57 & 57 & Cukup \\
\hline 22 & Sri Agustina & 7 & 7 & 15 & 15 & 5 & 49 & 49 & Kurang \\
\hline 23 & Sukerih & 10 & 10 & 15 & 15 & 10 & 60 & 60 & Cukup \\
\hline 24 & Wulan Dini & 10 & 10 & 15 & 15 & 10 & 60 & 60 & Cukup \\
\hline & Jumlah & 164 & 238 & 229 & 280 & 180 & 1091 & 1091 & \multirow{2}{*}{ Kurang } \\
\hline & Rata-rata & 8,25 & 9,92 & 12,04 & 14,17 & 8,96 & 53,33 & 53,3 & \\
\hline
\end{tabular}

Keterangan aspek yang dinilai :

1. Kelengkapan isi teks eksposisi.

2. Kelengkapan struktur teks eksposisi.

3. Kesesuaian kosakata.

4. Kesesuaian penggunaan bahasa dalam teks eksposisi.

5. Ketepatan mekanik.

Berdasarkan tabel tersebut, kemampuan memproduksi teks eksposisi siswa kelas $\mathrm{X}$ IPA 3 SMAN 2 Indramayu Tahun Pelajaran 2020/2021 sebelum (pretes) pembelajaran dengan model experiential learning termasuk kategori kurang, karena nilai ratarata yang diperoleh dari 24 siswa yaitu 53,33.Hal ini dilihat pada aspek isi sedang, karena penguasaan permasalahan terbatas, argumentasi, dan rekomendasi bersifat fakta kurang. Dengan ini rata-rata 8,25 (delapan koma dua puluh lima), pada aspek struktur sedang, karena siswa belum paham struktur yang terdapat pada teks eksposisi dan tidak terorganisir. Dengan ini rata-rata 9,92 (sembilan koma sembilan puluh dua), pada aspek kosakata baik, karena siswa mampu menguasai pemilihan kata namun kurang menguasai konjungsi dan pembentukkan kata. Dengan ini rata-rata 12,04 (dua belas koma nol empat). Pada aspek kaidah kebahasaan baik, karena siswa mampu menggunakan istilah namun siswa belum memahami makna abjektiva dan kalimat verba. Dengan ini rata-rata14,17 (empat belas koma tujuh belas), dan Pada mekanik sedang, karena siswa sedikit menguasai ejaan tapi belum menguasai tanda baca dan ketepatan memposisikan huruf kapital. Dengan ini rata-rata 8,96 (delapan koma sembilan puluh enam).

B. Hasil Kemampuan Memproduksi Teks Eksposisi Siswa Kelas X IPA 3 SMA Negeri 2 Indramayu Tahun Pelajaran 2020/2021 Sesudah Pembelajaran (Postes) dengan Model Experiential Learning 
BAHTERA INDONESIA:

ISSN 2541-3252

Jurnal Penelitian Pendidikan Bahasa dan Sastra Indonesia

Vol. 5, No. 2 Sep. 2020

\begin{tabular}{|c|c|c|c|c|c|c|c|c|c|}
\hline \multirow{2}{*}{ No } & \multirow{2}{*}{ Nama } & \multicolumn{5}{|c|}{ Aspek yang Dinilai } & \multirow{2}{*}{ Skor } & \multirow{2}{*}{ Nilai } & \multirow{2}{*}{ Klasifikasi } \\
\hline & & 1 & 2 & 3 & 4 & 5 & & & \\
\hline 1 & $\begin{array}{l}\text { Aa Anggara } \\
\text { Al A. }\end{array}$ & 20 & 20 & 20 & 20 & 20 & 100 & 100 & Baik Sekali \\
\hline 2 & $\begin{array}{l}\text { Abu Hasan } \\
\text { A. }\end{array}$ & 20 & 20 & 20 & 15 & 15 & 90 & 90 & Baik Sekali \\
\hline 3 & $\begin{array}{l}\text { Ais Indah } \\
\text { Ayu }\end{array}$ & 15 & 15 & 20 & 20 & 15 & 85 & 85 & Baik \\
\hline 4 & $\begin{array}{l}\text { Al Harist B. } \\
\mathrm{H} \text {. }\end{array}$ & 20 & 17 & 15 & 20 & 5 & 77 & 77 & Baik \\
\hline 5 & $\begin{array}{l}\text { Anisa } \\
\text { Murdiyana }\end{array}$ & 20 & 20 & 15 & 15 & 5 & 75 & 75 & Cukup \\
\hline 6 & $\begin{array}{l}\text { Cica Kartika } \\
\text { A. R. }\end{array}$ & 20 & 20 & 20 & 20 & 5 & 85 & 85 & Baik \\
\hline 7 & $\begin{array}{l}\text { Elok Faiqotul } \\
\text { H. }\end{array}$ & 10 & 10 & 20 & 20 & 15 & 75 & 75 & Cukup \\
\hline 8 & $\begin{array}{l}\text { Hasan } \\
\text { Nurudin R. }\end{array}$ & 20 & 20 & 20 & 20 & 10 & 90 & 90 & Baik Sekali \\
\hline 9 & Ica Kristi & 20 & 20 & 15 & 20 & 5 & 80 & 80 & Baik \\
\hline 10 & $\begin{array}{l}\text { Indah } \\
\text { Apriyana }\end{array}$ & 20 & 20 & 15 & 15 & 5 & 75 & 75 & Cukup \\
\hline 11 & Kartika & 20 & 20 & 15 & 15 & 15 & 85 & 85 & Baik \\
\hline 12 & $\begin{array}{l}\text { Kayla } \\
\text { Amelia L. }\end{array}$ & 15 & 15 & 15 & 20 & 10 & 75 & 75 & Cukup \\
\hline 13 & $\begin{array}{l}\text { Melisa Windi } \\
\text { F. }\end{array}$ & 20 & 20 & 15 & 15 & 5 & 75 & 75 & Cukup \\
\hline 14 & $\begin{array}{l}\text { Mely } \\
\text { Nurhasanah }\end{array}$ & 20 & 20 & 20 & 20 & 15 & 95 & 95 & Baik Sekali \\
\hline 15 & $\begin{array}{l}\text { Muhamad } \\
\text { Soltan }\end{array}$ & 20 & 20 & 15 & 20 & 15 & 90 & 90 & Baik Sekali \\
\hline 16 & $\begin{array}{l}\text { Ninda } \\
\text { Nurhayati }\end{array}$ & 20 & 20 & 15 & 20 & 15 & 90 & 90 & Baik Sekali \\
\hline 17 & Nisa Setyani & 10 & 10 & 20 & 15 & 20 & 75 & 75 & Cukup \\
\hline 18 & Nur Habibah & 15 & 15 & 10 & 20 & 15 & 75 & 75 & Cukup \\
\hline 19 & Nurhaenah & 15 & 15 & 20 & 15 & 10 & 75 & 75 & Cukup \\
\hline 20 & $\begin{array}{l}\text { Sandi } \\
\text { Subandi }\end{array}$ & 20 & 20 & 20 & 15 & 15 & 90 & 90 & Baik Sekali \\
\hline 21 & $\begin{array}{l}\text { Sofi } \\
\text { Khamelia }\end{array}$ & 20 & 20 & 15 & 15 & 15 & 85 & 85 & Baik \\
\hline 22 & Sri Agustina & 18 & 18 & 10 & 20 & 10 & 76 & 76 & Baik \\
\hline 23 & Sukerih & 20 & 20 & 15 & 20 & 15 & 90 & 90 & Baik Sekali \\
\hline 24 & Wulan Dini & 20 & 20 & 10 & 20 & 10 & 80 & 80 & Baik \\
\hline
\end{tabular}


BAHTERA INDONESIA:

ISSN 2541-3252

Jurnal Penelitian Pendidikan Bahasa dan Sastra Indonesia

Vol. 5, No. 2 Sep. 2020

\begin{tabular}{|c|c|c|c|c|c|c|c|c|}
\hline Jumlah & 438 & 435 & 395 & 435 & 285 & 1988 & 1988 & \multirow{2}{*}{ Baik } \\
\cline { 1 - 7 } Rata-rata & 18,25 & 18,13 & 16,46 & 18,13 & 11,88 & 82,83 & 82,83 & \\
\hline
\end{tabular}


Keterangan aspek yang dinilai:

1. Kelengkapan isi teks eksposisi.

2. Kelengkapan struktur teks eksposisi.

3. Kesesuaian kosakata.

4. Kesesuaian penggunaan bahasa dalam teks eksposisi.

5. Ketepatan mekanik.

Berdasarkan tabel tersebut, kemampuan memproduksi teks eksposisi siswa kelas X IPA 3 SMA Negeri 2 Indramayu Tahun Pelajaran 2020/2021 sesudah (postes) pembelajaran dengan model experiential learning termasuk kategori baik, karena nilai rata-rata yang diperoleh dari 24 siswa yaitu 82.83. Hal ini dilihat pada aspek kelengkapan isi baik sekali, karena menguasai topik pembahasan, pengetahuan, argumentasi, dan rekomendasi bersifat fakta. Dengan ini ratarata 18,25 (delapan belas koma dua puluh lima), pada aspek struktur baik sekali, karena tertata dengan baik, urutan logis (tesis, argumentasi, dan penegasan ulang). Dengan ini rata-rata18,13 (delapan belas koma tiga belas), pada aspek kosakata baik sekali, karena penguasaan konjugsi memadai, pemilihan kata tepat namun belum menguasai pembentukkan kata. Dengan ini rata-rata16,46 (enam belas koma empat puluh enam), pada aspek kaidah kebahasaan baik sekali, karena siswa menguasai kalimat verba, menguasai istilah namun belum menguasai makna abjektiva. Dengan ini rata-rata18,13 (delapan belas koma enam belas), dan pada aspek mekanik baik, karena siswa mampu menguassai tanda baca, ejaan yang sempurna namun sedikit menguasai ketepatan memposisikan huruf kapital. Dengan ini rata-rata11,88 (sebelas koma delapan puluh delapan).

\section{Pembahasan Kemampuan Memproduksi Teks Eksposisi Siswa Kelas X IPA 3 SMA Negeri 2 Indramayu Tahun Pelajaran 2020/2021}

Berdasarkan hasil pembelajaran memproduksi teks eksposisi pada siswa kelas X IPA 3, dapat disimpulkan beberapa hal sebagai berikut.

1. Hasil Analisis Kemampuan Memproduksi Teks Eksposisi Siswa Kelas X IPA 3 SMA Negeri 2 Indramayu Tahun Pelajaran 2020/2021 Sebelum (Pretes) dengan Model Experiential Learning

Berdasarkan uraian hasil pembelajaran memproduksi teks eksposisi tersebut dapat disimpulkan beberapa hal sebagai berikut.

1. Kelengkapan isi teks eksposisi

Berdasarkan kesimpulan dari analisis kelengkapan aspek isi teks eksposisi siswa kelas X IPA 3 SMA Negeri 2 Indramayu tahun pelajaran 2020/2021 sebelum (pretes) dengan model experiential learning yaitu siswa ke- 5, 14, dan 16, masing-masing mendapatkan skor 15. Dengan demikian, jumlah siswa yang mendapatkan skor 15 sebanyak 3 siswa atau dengan presentase $\frac{3}{24} \times 100=12,5 \%$. Sedangkan siswa ke- 19 , mendapatkan skor 12. Dengan demikian, jumlah siswa yang mendapatkan skor 12 sebanyak 1 siswa atau dengan presentase $\frac{1}{24} \times 100=4,16 \%$. Sedangkan siswa ke- 3, 6 , 8,23 , dan 24, masing-masing mendapatkan skor 10. Dengan demikian, jumlah siswa yang mendapatkan skor 10 sebanyak 5 siswa atau dengan presentase $\frac{5}{24} \times 100=$ 20,83\%. Sedangkan siswa ke- 4, 9, 10, 11, $12,13,15.18,20,21$, dan 22, masingmasing mendapatkan skor 7. Dengan demikian, jumlah siswa yang mendapatkan skor 7 sebanyak 9 siswa atau dengan prosentase $\frac{11}{24} \times 100=45,83 \%$. Sedangkan siswa ke- 1, dan 17, masing-masing mendapatkan skor 5. Dengan demikian, jumlah siswa yang mendapatkan skor 5 sebanyak 4 siswa atau dengan prosentase $\frac{2}{24} \times 100=8.33 \%$. Sedangkan siswa ke- 2 
dan 7, masing-masing mendapatkan skor 2 . Dengan demikian, jumlah siswa yang mendapatkan skor 2 sebanyak 2 siswa atau dengan presentase $\frac{2}{24} \times 100=8,33 \%$. Ratarata kemampuan memproduksi teks eksposisi pada kelengkapan isi teks eksposisi diperoleh 8,25 (delapan koma dua puluh lima).

\section{Kelengkapan struktur teks eksposisi}

Berdasarkan kesimpulan dari analisis kelengkapan struktur teks eksposisi siswa kelas X IPA 3 SMA Negeri 2 Indramayu tahun pelajaran 2020/2021 sebelum (pretes) dengan model experiential learning yaitu siswa ke- 5, 14 dan 16, masing-masing mendapatkan skor 15 . Dengan demikian, jumlah siswa yang mendapatkan skor 15 sebanyak 2 siswa atau dengan presentase $\frac{3}{24} \times 100=12,5 \%$. Sedangkan siswa ke- 19 . Mendapatkan skor 12. Dengan demikian, jumlah siswa yang mendapatkan skor 15 sebanyak 1 siswa atau dengan presentase $\frac{1}{24} \times 100=4,16 \%$. Sedangkan siswa ke- 3,4 , $6,8,9,10,11,12,13,15,17,18,21,23$, dan 24, masing-masing mendapatkan skor 10. Dengan demikian, jumlah siswa yang mendapatkan skor 10 sebanyak 15 siswa atau dengan presentase $\frac{15}{24} \times 100=62,5 \%$. Sedangkan siswa ke- 1, 20, dan 22, masingmasing mendapatkan skor 7. Dengan demikian, jumlah siswa yang mendapatkan skor 7 sebanyak 3 siswa atau dengan presentase $\frac{3}{24} \times 100=12,5 \%$. Sedangkan siswa ke- 2 dan 7, masing-masing mendapatkan skor 5. Dengan demikian, jumlah siswa yang mendapatkan skor 5 sebanyak 2 siswa atau dengan presentase $\frac{2}{24} \times 100=8,33 \%$. Rata-rata kemampuan memproduksi teks eksposisi pada kelengkapan struktur eksposisi diperoleh 9,92 (sembilan koma sembilan puluh dua).

3. Kesesuaian kosakata
Berdasarkan kesimpulan dari analisis kesesuaian kosakata teks eksposisi siswa kelas X IPA 3 SMA Negeri 2 Indramayu tahun pelajaran 2020/2021 sebelum (pretes) dengan model experiential learning yaitu siswa ke- 4, 5, 6, 10, 14, 15, 17, 18, 21, 22, 23 , dan 24, masing-masing mendapatkan skor 15. Dengan demikian, jumlah siswa yang mendapatkan skor 15 sebanyak 12 siswa atau dengan presentase $\frac{12}{24} \times 100=$ $50 \%$. Sedangkan siswa ke- 20, mendapatkan skor 12. Dengan demikian, jumlah siswa yang mendapatkan skor 12 sebanyak 1 siswa atau dengan presentase $\frac{1}{24} \times 100=4,16 \%$. Sedangkan siswa ke- 1,2 , $3,8,11,12$, 13, dan 16, masing-masing mendapatkan skor 10. Dengan demikian, jumlah siswa yang mendapatkan skor 10 sebanyak 8 siswa atau dengan presentase $\frac{8}{24} \times 100=33,33 \%$. Sedangkan siswa ke- 9, mendapatkan skor 7. Dengan demikian, jumlah siswa yang mendapatkan skor 7 sebanyak 1 siswa atau dengan presentase $\frac{1}{24} \times 100=4,16 \%$. Sedangkan siswa ke- 7 , dan 19, mendapatkan skor 5. Dengan demikian, jumlah siswa yang mendapatkan skor 5 sebanyak 2 siswa atau dengan presentase $\quad \frac{2}{24} \times 100=8,33 \%$. Rata-rata kemampuan memproduksi teks eksposisi pada kesesuaian kosakata teks eksposisi diperoleh 12,04 (dua belas koma nol empat).

4. Kesesuaian penggunaan bahasa dalam teks eksposisi

Berdasarkan kesimpulan dari analisis kesesuaian penggunaan bahasa dalam teks eksposisi siswa kelas X IPA 3 SMA Negeri 2 Indramayu tahun pelajaran 2019/2020 sebelum (pretes) dengan model experiential learning yaitu siswa ke- 1, 2, 3, 4, 5, 6, 8, 9, $10,11,14,15,16,17,19,20,21,22,23$, dan 24, mendapatkan skor 15. Dengan demikian, jumlah siswa yang mendapatkan skor 15 sebanyak 20 siswa atau dengan presentase $\frac{20}{24} \times 100=83.33 \%$. Sedangkan 
siswa ke- 7, 12, 13, dan 18, masing-masing mendapatkan skor 10. Dengan demikian, jumlah siswa yang mendapatkan skor 10 sebanyak 4 siswa atau dengan presentase $\frac{4}{24} \times 100=16,66 \%$. Rata-rata kemampuan memproduksi teks eksposisi pada kesesuaian penggunaan bahasa dalam teks eksposisi diperoleh 14,17 (empat belas koma tujuh belas).

\section{Ketepatan mekanik}

Berdasarkan kesimpulan dari analisis ketepatan mekanik teks eksposisi siswa kelas X IPA 3 SMA Negeri 2 Indramayu tahun pelajaran 2020/2021 sebelum (pretes) dengan model experiential learning yaitu siswa ke-12, mendapatkan skor 20. Dengan demikian, jumlah siswa yang mendapatkan skor 20 sebanyak 1 siswa atau dengan presentase $\frac{1}{24} \times 100=4,16 \%$. Sedangkan siswa ke- 2, dan 11, masing-masing mendapatkan skor 15. Dengan demikian, jumlah siswa yang mendapatkan skor 15 sebanyak 2 siswa atau dengan presentase $\frac{2}{24} \times 100=8,33 \%$. Sedangkan siswa ke- 1,3 , $7,8,10,13,14,15,18,21,23$, dan 24, mendapatkan skor 10. Dengan demikian, jumlah siswa yang mendapatkan skor 10 sebanyak 12 siswa atau dengan presentase $\frac{12}{24} \times 100=50 \%$. Sedangkan siswa ke- 4, 5, 6, $9,16,17,19,20$, dan 22, masing-masing mendapatkan skor 5. Dengan demikian, jumlah siswa yang mendapatkan skor 5 sebanyak 9 siswa atau dengan presentase $\frac{9}{24} \times 100=37,5$. Rata-rata kemampuan memproduksi teks eksposisi pada ketepatan mekanik teks eksposisi diperoleh 8,95 (delapan koma sembilan puluh lima).

Berdasarkan uraian di atas dapat disimpulkan bahwa rata-rata kemampuan memproduksi teks eksposisi siswa kelas $\mathrm{X}$ IPA sebelum pembelajaran dengan menggunakan model experiential learning termasuk kategori baik, dengan jumlah tes awal (pretes) yaitu 53,33 (lima puluh tiga koma tiga puluh tiga).

\section{Hasil Analisis Kemampuan Memproduksi Teks Eksposisi Siswa Kelas X IPA 3 SMA Negeri 2 Indramayu Tahun Pelajaran 2020/2021 Sesudah (Postes) dengan Model Experiential Learning}

Berdasarkan uraian hasil pembelajaran memproduksi teks eksposisi tersebut dapat disimpulkan beberapa hal sebagai berikut.

1. Kelengkapan isi teks eksposisi

Berdasarkan kesimpulan dari analisis kelengkapan aspek isi teks eksposisi siswa kelas X IPA 3 SMA Negeri 2 Indramayu tahun pelajaran 2020/2021 sesudah (postes) dengan model experiential learning yaitu siswa ke- 1, 2, 4, 5, 6, 8, 9, $10,11,13,14,15,16,20,21,23$, dan 24 , masing-masing mendapatkan skor 20. Dengan demikian, jumlah siswa yang mendapatkan skor 20 sebanyak 17 siswa atau dengan presentase $\frac{17}{24} \times 100=70,83 \%$. Sedangkan siswa ke-22, mendapatkan skor 18. Dengan demikian, jumlah siswa yang mendapatkan skor 18 sebanyak 1 siswa atau dengan presentase $\frac{1}{24} \times 100=4,16 \%$. Sedangkan siswa ke- 3, 12, 18, dan 19, masing-masing mendapatkan skor 15 . Dengan demikian, jumlah siswa yang mendapatkan skor 15 sebanyak 4 siswa atau dengan presentase $\frac{4}{24} \times 100=16.66 \%$. Sedangkan siswa ke- 7 dan 17, masingmasing mendapatkan skor 10. Dengan demikian, jumlah siswa yang mendapatkan skor 10 sebanyak 2 siswa atau dengan presentase $\frac{2}{24} \times 100=8,33 \%$. Rata-rata kemampuan memproduksi teks eksposisi pada kelengkapan isi teks eksposisi diperoleh 18,25 (delapan belas koma dua puluh lima).

\section{Kelengkapan struktur teks eksposisi}


Berdasarkan kesimpulan dari analisis kelengkapan struktur teks eksposisi siswa kelas X IPA 3 SMA Negeri 2 Indramayu tahun pelajaran 2019/2020 sesudah (postes) dengan model experiential learning yaitu siswa ke- 1, 2, 5, 6, 8, 9, 10, 11, 13, 14, 15, $16,20,21,23$, dan 24, masing-masing mendapatkan skor 20. Dengan demikian, jumlah siswa yang mendapatkan skor 20 sebanyak 16 siswa atau dengan presentase $\frac{16}{24} \times 100=66,66 \%$. Sedangkan siswa ke- 22, mendapatkan skor 18. Dengan demikian, jumlah siswa yang mendapatkan skor 18 sebanyak 1 siswa atau dengan presentase $\frac{1}{24} \times 100=4,16 \%$. Sedangkan siswa ke- 4, mendapatkan skor 17. Dengan demikian, jumlah siswa yang mendapatkan skor 17 sebanyak 1 siswa atau dengan presentase $\frac{1}{24} \times 100=4,16 \%$. Sedangkan siswa ke- 3,12 , 18, dan 19, masing-masing mendapatkan skor 15. Dengan demikian, jumlah siswa yang mendapatkan skor 15 sebanyak 4 siswa atau dengan presentase $\frac{4}{24} \times 100=$ $16.66 \%$. Sedangkan siswa ke- 7 dan 17, masing-masing mendapatkan skor 10. Dengan demikian, jumlah siswa yang mendapatkan skor 10 sebanyak 2 siswa atau dengan presentase $\frac{2}{24} \times 100=8,33 \%$. Ratarata kemampuan memproduksi teks eksposisi pada kelengkapan struktur eksposisi diperoleh 18,13 (delapan belas koma tiga belas)

\section{Kesesuaian kosakata}

Berdasarkan kesimpulan dari analisis kesesuaian kosakata teks eksposisi siswa kelas X IPA 3 SMA Negeri 2 Indramayu tahun pelajaran 2019/2020 sesudah (postes) dengan model experiential learning yaitu siswa ke- 1, 2, 3, 6, 7, 8, 14, 17, 19, dan 20, mendapatkan skor 20. Dengan demikian, jumlah siswa yang mendapatkan skor 20 sebanyak 10 siswa atau dengan presentase $\frac{10}{24} \times 100=41,66 \%$. Sedangkan siswa ke- 4,5 ,
$9,10,11,12,13,15,16,21$, dan 23, masingmasing mendapatkan skor 15. Dengan demikian, jumlah siswa yang mendapatkan skor 15 sebanyak 11 siswa atau dengan presentase $\frac{11}{24} \times 100=45,83 \%$. Sedangkan siswa ke- 18, 22, dan 24, mendapatkan skor 10. Dengan demikian, jumlah siswa yang mendapatkan skor 10 sebanyak 3 siswa atau dengan presentase $\frac{3}{24} \times 100=12,5 \%$. Ratarata kemampuan memproduksi teks eksposisi pada kesesuaian kosakata teks eksposisi diperoleh 16,46 (enam belas koma empat puluh enam).

\section{Kesesuaian penggunaan bahasa} dalam teks eksposisi

Berdasarkan kesimpulan dari analisis kesesuaian penggunaan bahasa dalam teks eksposisi siswa kelas X IPA 3 SMA Negeri 2 Indramayu tahun pelajaran 2019/2020 sesudah (postes) dengan model experiential learning yaitu siswa ke- 1, 3, 4, 6, 7, 8, 9, $12,14,15,16,18,22,23$, dan 24, masingmasing mendapatkan skor 20. Dengan demikian, jumlah siswa yang mendapatkan skor 20 sebanyak 15 siswa atau dengan presentase $\frac{15}{24} \times 100=62,5 \%$. Sedangkan siswa ke- 2, 5, 10, 11, 13, 17, 19, 20, dan 21, masing-masing mendapatkan skor 15 . Dengan demikian, jumlah siswa yang mendapatkan skor 15 sebanyak 9 siswa atau dengan presentase $\frac{9}{24} \times 100=37,5 \%$. Ratarata kemampuan memproduksi teks eksposisi pada kesesuaian penggunaan bahasa dalam teks eksposisi diperoleh 18,13 (delapan belas koma tiga belas).

\section{Ketepatan mekanik}

Berdasarkan kesimpulan dari analisis ketepatan mekanik teks eksposisi siswa kelas X IPA 3 SMA Negeri 2 Indramayu tahun pelajaran 2020/2021 sesudah (postes) dengan model experiential learning yaitu siswa ke- 1 dan 17, masing-masing mendapatkan skor 20. Dengan demikian, jumlah siswa yang mendapatkan skor 20 
sebanyak 2 siswa atau dengan presentase $\frac{2}{24} \times 100=8,33 \%$. Sedangkan siswa ke- 2, 3, $7,11,14,15,16,18,20,21$, dan 23, masingmasing mendapatkan skor 15. Dengan demikian, jumlah siswa yang mendapatkan skor 15 sebanyak 11 siswa atau dengan presentase $\frac{11}{24} \times 100=45,83 \%$. Sedangkan siswa ke- $8,12,19,22$, dan 24, mendapatkan skor 10. Dengan demikian, jumlah siswa yang mendapatkan skor 10

Berdasarkan uraian di atas dapat disimpulkan bahwa rata-rata kemampuan memproduksi teks eksposisi siswa kelas $\mathrm{X}$ IPA sesudah pembelajaran dengan model experiential learning termasuk kategori

E. Pengaruh Metode Experiential Learning dalam Pembelajaran Memproduksi Teks Eksposisi di Kelas X IPA 3 SMA Negeri 2 Indramayu Tahun Pelajaran 2020/2021

\section{Pengaruh Model Experiential Learning dalam Pembelajaran Memproduksi Teks Eksposisi Berdasarkan Rumus Uji-t}

Pengaruh pembelajaran yang dilaksanakan dapat dilihat dari hasil belajar siswa melalui penelitian dan penilaian. Penilaian kemampuan siswa dalam memproduksi teks eksposisi berupa tes awal (pretes) dan tes akhir (postes) yang dilakukan di kelas X IPA 3 SMA Negeri 2 Indramayu Tahun Pelajaran 2020/2021. Hasil yang diperoleh adalah sebagai berikut. sebanyak 5 siswa atau dengan presentase $\frac{5}{24} \times 100=20,83 \%$. Sedangkan siswa ke- 4,5 , $6, \quad 9,10$, dan 13, masing-masing mendapatkan skor 5. Dengan demikian, jumlah siswa yang mendapatkan skor 5 sebanyak 6 siswa atau dengan presentase $\frac{6}{24} \times 100=25$. Rata-rata kemampuan memproduksi teks eksposisi pada ketepatan mekanik teks eksposisi diperoleh 11,88 (sebelas koma delapan puluh delapan).

baik, dengan jumlah tes akhir (postes) yaitu 82,83 (delapan puluh dua koma delapan puluh tiga). 
Tabel 4.3

Nilai Pretes dan Postes Kemampuan Memproduksi Teks Eksposisi Siswa Kelas X IPA 3 SMA Negeri 2 Indramayu Tahun Pelajaran 2020/2021

\begin{tabular}{|c|c|c|c|c|c|c|}
\hline \multirow[b]{2}{*}{ No } & \multirow[b]{2}{*}{ Nama Siswa } & \multicolumn{2}{|c|}{ Nilai Siswa } & \multirow[b]{2}{*}{$\begin{array}{c}\mathbf{d}=(\mathbf{Y}- \\
\mathbf{X})\end{array}$} & \multirow{2}{*}{$\begin{array}{c}\mathrm{Xd}=(d- \\
m d)\end{array}$} & \multirow[b]{2}{*}{$(\mathbf{X d})^{2}$} \\
\hline & & $\begin{array}{l}\text { Pretes } \\
\text { X }\end{array}$ & $\begin{array}{c}\text { postes } \\
Y\end{array}$ & & & \\
\hline 1 & Aa Anggara Al A. & 47 & 100 & 53 & $-23,50$ & 552 \\
\hline 2 & Abu Hasan A. & 47 & 90 & 43 & $-41,77$ & 1745 \\
\hline 3 & Ais Indah Ayu & 55 & 85 & 30 & $-30,00$ & 900 \\
\hline 4 & Al Harist Bahtera H. & 52 & 77 & 25 & $-25,00$ & 625 \\
\hline 5 & Anisa Murdiyana & 65 & 75 & 10 & $-10,00$ & 100 \\
\hline 6 & Cica Kartika A. R & 55 & 85 & 30 & $-30,00$ & 900 \\
\hline 7 & Elok Faiqotul Himah & 32 & 75 & 43 & $-43,00$ & 1849 \\
\hline 8 & Hasan Nurudin R. & 55 & 90 & 35 & $-35,00$ & 1225 \\
\hline 9 & Ica Kristi & 44 & 80 & 36 & $-36,00$ & 1296 \\
\hline 10 & Indah Apriyana & 57 & 75 & 18 & $-18,00$ & 324 \\
\hline 11 & Kartika & 57 & 85 & 28 & $-28,00$ & 784 \\
\hline 12 & Kayla Amelia L. & 57 & 75 & 18 & $-18,00$ & 324 \\
\hline 13 & Melisa Windi F. & 47 & 75 & 28 & $-28,00$ & 784 \\
\hline 14 & Mely Nurhasanah & 70 & 95 & 25 & $-25,00$ & 625 \\
\hline 15 & Muhamad Soltan & 57 & 90 & 33 & $-33,00$ & 1089 \\
\hline 16 & Ninda Nurhayati & 60 & 90 & 30 & $-30,00$ & 900 \\
\hline 17 & Nisa Setyani & 50 & 75 & 25 & $-25,00$ & 625 \\
\hline 18 & Nur Habibah & 52 & 75 & 23 & $-23,00$ & 529 \\
\hline 19 & Nurhaenih & 49 & 75 & 26 & $-26,00$ & 676 \\
\hline 20 & Sandi Subandi & 46 & 90 & 44 & $-44,00$ & 1936 \\
\hline 21 & Sofi Khamelia & 57 & 85 & 28 & $-28,00$ & 784 \\
\hline 22 & Sri Agustina & 49 & 76 & 27 & $-27,00$ & 729 \\
\hline 23 & Sukerih & 60 & 90 & 30 & $-30,00$ & 900 \\
\hline 24 & Wulan Dini & 60 & 80 & 20 & $-20,00$ & 400 \\
\hline & Jumlah & 1280 & 1988 & 708 & $-677,27$ & 20601 \\
\hline & Rata-Rata & 53,33 & 82,83 & 29,50 & $-28,22$ & 858 \\
\hline
\end{tabular}


Berdasarkan tabel di atas, diketahui bahwa nilai rata-rata pretes 53,33 (lima puluh tiga koma tiga puluh tiga) dan nilai rata-rata postes 82,83 (delapan puluh dua koma delapan puluh tiga). Dengan demikian, rata-rata tersebut mengalami peningkatan kenaikan yaitu 29,50 (dua puluh sembilan koma lima puluh). Selanjutnya nilai tersebut diolah dengan rumus uji-t yaitu sebagai berikut.

1. Mencari d

$$
\begin{aligned}
\mathrm{d} & =\text { Jumlah Postes }- \text { Pretes } \\
& =1988-1280
\end{aligned}
$$

4. Mencari t0 (thitung)

$$
\begin{aligned}
& t=\frac{\mathrm{Md}}{\sqrt{\left(\frac{\sum X d^{2}}{\mathrm{~N}(\mathrm{~N}-1)}\right)}} \\
& =\frac{\mathrm{Md}}{\sqrt{\frac{20601}{24(24-1)}}} \\
& =\frac{29,50}{\sqrt{\frac{20601}{24(23)}}} \\
& =\frac{\frac{29,50}{\sqrt{\frac{20601}{552}}}}{=} \\
& =\frac{29,50}{\sqrt{37,32}} \\
& =\frac{29,50}{6,10} \\
& =4,83
\end{aligned}
$$

5. Menentukan $t_{\text {tabel }}$

Taraf Signifikan $\mathrm{a}=0,5$

Derajat kebebasan $\mathrm{db}=\mathrm{N}-1=24-$ $1=23$ jadi, $\mathrm{t}_{\text {tabel }}=1,71$

6. Kriteria Pengembalian Keputusan

Hipotesis dalam penelitian ini adalah sebagai berikut.

$\begin{array}{rlr}\mathrm{H}_{0}: t_{\text {hitung }}<t_{\text {tabel }} & \text { : Model } & \text { experiential } \\ & \text { learning } & \text { tidak } \\ & \text { efektif } & \text { dalam } \\ & \text { pembelajaran } & \text { teks } \\ & \text { eksposisi } & \text { siswa } \\ & \text { kelas X } & \text { SMA } \\ & \text { Negeri } & 2 \\ & \text { Indramayu } & \text { Tahun } \\ & \text { Pelajaran } & \\ & \text { 2020/2021. }\end{array}$

$$
=708
$$

2. Mencari rata-rata (mean) dari deviasi (d) antara pretes dan postes.

$$
\begin{aligned}
\mathrm{Md} & =\frac{\sum d}{N} \\
\mathrm{Md} & =\frac{708}{24} \\
\mathrm{Md} & =29,5
\end{aligned}
$$

3. Mencari df atau db

$$
\begin{aligned}
\mathrm{df} & =\mathrm{N}-1 \\
& =24-1 \\
& =23
\end{aligned}
$$

$\mathrm{H}_{0}: t_{\text {hitung }}>t_{\text {tabel }} \quad$ : Model experiential learning efektif dalam pembelajaran teks eksposisi siswa kelas $\mathrm{X}$ SMA Negeri 2 Indramayu Tahun Pelajaran 2020/2021.

Berdasarkan hasil dari pengelolahan data tersebut, diperoleh thitung 4,83 (empat koma delapan puluh tiga), sedangkan tabel 1,71 (satu koma tujuh belas) dengan derajat bebas $(\mathrm{db})=23$ dan taraf signifikan $5 \%=0,0$. Karena nilai $t_{\text {hitung }}$ lebih besar dari $\mathrm{t}_{\text {tabel }}(4,83>1,71)$, maka $\mathrm{h}_{0}$ ditolak dan $\mathrm{H}_{\mathrm{a}}$ diterima. Dapat disimpulkan bahwa model experiential learning efektif dalam pembelajaran teks eksposisi siswa kelas $\mathrm{X}$ SMA Negeri 2 Indramayu Tahun Pelajaran 2020/2021. 
F. Pengaruh Model Experiential Learning dalam Pembelajaran Memproduksi Teks Eksposisi Berdasarkan Nilai Ketuntasan Minimal (KKM)

Pengaruh metode experiential learning dalam pembelajaran memproduksi teks eksposisi dapat diketahui dengan cara melihat presentasi pencapaian KKM siswa

Tabel 4.4

Nilai Postes Siswa Kelas X IPA SMA Negeri 2 Indramayu Tahun Pelajaran 2020/2021 Berdasarkan Kriteria Ketuntasan Minimal (KKM)

\begin{tabular}{|c|l|c|c|c|c|}
\hline \multirow{2}{*}{ No } & \multirow{2}{*}{ Nama Siswa } & \multirow{2}{*}{ KKM } & Nilai & \multirow{2}{*}{ Kategori Nilai } & Keterangan \\
\cline { 4 - 5 } $\mathbf{1}$ & Aa Anggara Al A. & 75 & 100 & Baik Sekali & Tuntas \\
\hline $\mathbf{2}$ & Abu Hasan A. & 75 & 90 & Baik Sekali & Tuntas \\
\hline $\mathbf{3}$ & Ais Indah Ayu & 75 & 85 & Baik & Tuntas \\
\hline $\mathbf{4}$ & Al Harist B. H. & 75 & 77 & Baik & Tuntas \\
\hline $\mathbf{5}$ & Anisa Murdiyana & 75 & 75 & Cukup & Tuntas \\
\hline $\mathbf{6}$ & Cica Kartika A. R & 75 & 85 & Baik & Tuntas \\
\hline $\mathbf{7}$ & Elok Faiqotul H. & 75 & 75 & Cukup & Tuntas \\
\hline $\mathbf{8}$ & Hasan Nurudin R. & 75 & 90 & Baik Sekali & Tuntas \\
\hline $\mathbf{9}$ & Ica Kristi & 75 & 80 & Baik & Tuntas \\
\hline $\mathbf{1 0}$ & Indah Apriyana & 75 & 75 & Cukup & Tuntas \\
\hline $\mathbf{1 1}$ & Kartika & 75 & 85 & Baik & Tuntas \\
\hline $\mathbf{1 2}$ & Kayla Amelia L. & 75 & 75 & Cukup & Tuntas \\
\hline $\mathbf{1 3}$ & Melisa Windi F. & 75 & 75 & Cukup & Tuntas \\
\hline $\mathbf{1 4}$ & Mely Nurhasanah & 75 & 95 & Baik Sekali & Tuntas \\
\hline $\mathbf{1 5}$ & Muhamad Soltan & 75 & 90 & Baik Sekali & Tuntas \\
\hline $\mathbf{1 6}$ & Ninda Nurhayati & 75 & 90 & Baik Sekali & Tuntas \\
\hline $\mathbf{1 7}$ & Nisa Setyani & 75 & 75 & Cukup & Tuntas \\
\hline $\mathbf{1 8}$ & Nur Habibah & 75 & 75 & Cukup & Tuntas \\
\hline $\mathbf{1 9}$ & Nurhaenih & 75 & 75 & Cukup & Tuntas \\
\hline $\mathbf{2 0}$ & Sandi Subandi & 75 & 90 & Baik Sekali & Tuntas \\
\hline $\mathbf{2 1}$ & Sofi Khamelia & 75 & 85 & Baik & Tuntas \\
\hline $\mathbf{2 2}$ & Sri Agustina & 75 & 76 & Baik & Tuntas \\
\hline $\mathbf{2 3}$ & Sukerih & 75 & 90 & Baik Sekali & Tuntas \\
\hline $\mathbf{2 4}$ & Wulan Dini & 75 & 80 & Baik & Tuntas \\
\hline & & & & & \\
\hline
\end{tabular}

Program Studi Pendidikan Bahasa dan Sastra Indonesia 
Berdasarkan tabel di atas, diketahui bahwa 24 siswa mendapatkan nilai di atas KKM. Untuk menghitung presentase ketercapaian KKM dapat dilakukan dengan cara sebagai berikut.

$$
\begin{gathered}
\frac{\text { Jumlah siswa yang mencapai KKM }}{\text { Jumlah Siswa Keseluruhan }} \times 100 \\
\frac{24}{24} \times 100=100 \%
\end{gathered}
$$

Hasil presentase pembelajaran memproduksi teks eksposisi dengan metode experiential learning dalam satu

\section{KESIMPULAN}

Perbandingan

kemampuan memproduksi teks eksposisi siswa kelas $\mathrm{X}$ IPA 3 SMA Negeri 2 Indramayu Tahun Pelajaran 2020/2021 antara sebelum pembelajaran dengan sesudah pembelajaran, sebelum pembelajaran (pretes) termasuk kategori kurang. Hal ini dapat dilihat dari nilai rata-rata sebelum pembelajaran sebesar 53,33. Sedangkan sesudah pembelajaran (postes) termasuk kategori baik. Hal ini dapat dilihat dari nilai rata-rata sesudah pembelajaran sebesar 82,83. Dengan demikian terjadi peningkatan kemampuan dari sebelum pembelajaran ke sesudah pembelajaran yaitu kategori kurang menjadi kategori baik. Meningkatnya kemampuan memproduksi teks eksposisi siswa kelas $\mathrm{X}$ IPA 3 SMA Negeri 2 Indramayu Tahun Pelajaran 2020/2021 sebelum pembelajaran (pretes) dan setelah pembelajaran (postes) dikarenakan sebelum pembelajaran (pretes) siswa hanya diberi materi dan latihan dengan metode ceramah, sedangkan sesudah pembelajaran (postes) siswa diberi materi dan latihan dengan model experiential learning. Selain itu peneliti dan siswa melakukan pembelajaran untuk menambah pengetahuan dan memperdalam materi. Sehingga terlihat naiknya nilai ratarata signifikan dari sebelum pembelajaran kelas yang berjumlah 24 siswa mencapai $100 \%$, sehingga model experiential learning dikatakan berpengaruh dalam pembelajaran memproduksi teks eksposisi.

(pretes) dengan sesudah pembelajaran (postes) menggunakan model experiential learning.

Model experiential learning berpengaruh dalam pembelajaran memproduksi teks eksposisi di kelas X IPA 3 SMA Negeri 2 Indramayu Tahun Pelajaran 2020/2021. Hal ini dibuktikan dari hasil perhitungan dengan rumus uji-t diperoleh nilai thitung 4,83 dan nilai $t_{\text {tabel }} 1,71$ pada taraf signifikan 0,05. Hal ini menunjukkan bahwa Ho ditolak dan $\mathrm{Ha}$ diterima. Selain itu, pengaruh model experiential learning dilihat juga dari ketercapaian KKM keseluruhan siswa berjumlah 24 dalam satu kelas memperoleh persentase siswa yang lulus $100 \%$. Berdasarkan hasil perhitungan tersebut, nilai $t_{\text {hitung }}$ lebih besar dari $t_{\text {tabel, }}$ dan jumlah siswa yang lulus lebih dari 75\%, maka dapat disimpulkan bahwa model experiential learning berpengaruh dalam pembelajaran memproduksi teks eksposisi.

\section{DAFTAR PUSTAKA}

Admin. 2016. "3 Teks Eksposisi Tentang Lingkungan Sekolah dalam Bahasa Indonesia"(Online).https://ruangseni. com/3-teks-eksposisi-tentanglingkungan-sekolah-dalam-bahasaindonesia/. (diakses 10 September 2019). 
Admin. 2019. "Contoh Teks Eksposisi Tentang Internet"(Online). https://www.contohteks.id/contohteks-eksposisi-internet/. (diakses 10 September 2019).

Arikunto, Suharsimi. 2010. Prosedur Penelitian. Jakarta: PT Rineka Cipta.

Arikunto, Suharsimi. 2012. Dasar-dasar Evaluasi Pendidikan. Jakarta: Bumi Aksara.

Brown, Douglas. Edisi kelima. Prinsip Pembelajaran dan Pengajaran Bahasa. San Francisco, California.

Dardjowidjojo, $\quad$ Soenjono. 2016. Psikolinguistik Pengantar Pemahaman Bahasa Manusia. Jakarta: Yayasan Pustaka Obor Indonesia.

Eriyanto. 2006. Analisis Wacana Pengantar Analisis Teks Media. Yogyakarta: PT. LkiS Pelangi Aksara Yogyakarta.

Fathurrohman, Muhammad. 2017. Modelmodel Pembelajaran Inovatif. Jogjakarta: Ar-Ruzz Media.

Gunawan, Farid. 2019. Modul Aplikasi Exel untuk Penelitian. Universitas Wiralodra.

Heriawan, Adang, Daarmajati, dan Arip Senjaya. 2012. Metodologi Pembelajaran Kajian Teoritis Praktis. Banten: LP3G (lembaga Pembinaan dan Pengembangan Profesi Guru).

Herlina, Eli. 2016. Bekal Buat Menulis. Yogyakarta:K-Media.

Hidayat, Isnu. 2019. 50 Strategi Pembelajaran Populer. Yogyakarta: Diva Press.
Huda, Miftahul. 2014. Model-model Pengajaran dan Pembelajaran. Yogyakarta: Pustaka Pelajaran.

Iskandarwasid. 2016. Strategi Pembelajaran Bahasa. Bundung: PT Remaja Rosdakarya

Jauhari, Heri. 2013. Terampil Mengarang. Bandung: Nuansa Cendekia.

Kemendikbud. 2017. Bahasa Indonesia kelas X. Balitbang: Pusat Kurikulum dan Pembukuan.

Kohar, Dadun. 2016. Bahan Perkuliahan Perencanaan Pembelajaran Bahasa Indonesia. Indramayu: tidak di terbitkan.

Kosasih, E. 2016. Jenis-jenis Teks. Bandung: Yrama Widya.

Lestari, Ike Widya. 2011. "Pembelajaran Menulis Karangan Argumentasi dengan Metode Team Assisted Individualization di kelas X SMK Negeri 2 Indramayu Tahun Pelajaran 2010/2011". Skripsi Bahasa dan Sastra Indonesia Universitas Wiralodra Indramayu. Univarsitas Wiralodra.

Mahmuri. 2014. "Pembelajaran Menulis Karangan Narasi dengan Menggunakan Metode Team Assisted Individualization di kelas X SMA Negeri 1 Lohbener Tahn pelajaran 2013/2014". Skripsi Bahasa dan Sastra Indonesia Universitas wiralodra Indramayu. Universitas Wiralodra.

Mahsun. 2018. Pembelajaran Bahasa Indonesia Berbasis Teks. Depok: Rajawali Pers.

Mulyasa. 2017. Kurikulum 2013. Bandung: PT. Remaja Rosdakarya. 
Nurgiyantoro, Burhan. 2014. Penilaian Pembelajaran Bahasa Berbasis Kompetensi. Yogyakarta: BPFEYOGYAKARTA.

Priyatni, Endah Tri. 2014. Desain Pembelajaran Bahasa Indonesia dalam Kurikulum 2013. Jakarta: PT Bumi Aksara

Rakasiwi, widya ayu. 2012. "Efektivitas Metode Pembelajaran Kooperatif Tipe Students Teams Achievement Divisions (STAD) untuk Meningkatkan Prestasi Belajar Tata Hidang Siswa Kelas X Jurusan Jasa Boga di SMK Negeri 4 Yogyakarta"(Online). https://eprints.uny.ac.id/8472/. (diakses 20 Juni 2019)

Rusman. 2014. Model-model Pembelajaran. Jakarta: PT Raja Grafindo Persada.

Sagala, Syaiful. 2013. Konsep dan Makna Pembelajaran. Bandung: Alfabeta.

Semi, Atar. 2007. Dasar-dasar keterampilan Menulis. Bandung: Angkasa.

Slavin, Robert E. 2005. Cooperative Learning. Bandung: Nusa Media.

Sobur, Alex. 2012. Analisis Teks Media. Bandung: PT. Remaja Rosdakarya.

Sugiyono. 2018. Metode Penelitian Pendidikan: Pendekatan Keantitatif, Kualitatif, dan $R \& D$. Bandung: Alfabeta.
Tarigan, Henry Guntur. 2008. Menulis Sebagai Suatu Keterampilan Berbahasa. Bandung: Angkasa.

Yani, Ahmad. 2013. Mindset Kurikulum 2013. Bandung: Alfabeta.

Zainurrahman. 2018. Menulis dari Teori Hingga Praktik (Penawar Racun Plagiarisme). Bandung: ALFABETA. 
